\title{
DETERMINATION OF THE ACTIVATION ENERGY OF POLAR FIRN BY D.C. RESISTIVITY MEASUREMENTS
}

\author{
By M. P. Hochstein and G. F. Risk \\ (Geophysical Survey, Geophysics Division, D.S.I.R., Wellington, New Zealand)
}

\begin{abstract}
The activation energy $\epsilon_{\mathrm{el}}$ of polar firn samples determined by D.C. resistivity measurements is a function of temperature and density. In the temperature range $-2{ }^{\circ} \mathrm{C}$. to $-10^{\circ} \mathrm{C}$. $\epsilon_{\mathrm{el}}$ decreases with decreasing temperature reaching a nearly constant value for temperatures colder than $-10^{\circ} \mathrm{C}$.; in the temperature range $-10^{\circ} \mathrm{C}$. to $-21^{\circ} \mathrm{C}$. $\epsilon_{\mathrm{el}}$ was found to decrease with increasing density and to lie between $0.7 \mathrm{eV}$. and $0.4 \mathrm{eV}$.
\end{abstract}

RÉsumé. Détermination de l'énergie d'activation du névé polaire par des mesures de résistivité à courant continu. L'énergie d'activation $\epsilon_{\mathrm{el}}$ des échantillons du névé polaire, déterminée par des mesures de résistivité à courant continu, est une fonction de la température et de la densité. Dans l'intervalle entre $-2^{\circ} \mathrm{C}$ et $-\mathrm{IO}^{\circ} \mathrm{C}$, $\epsilon_{\mathrm{el}}$ décroit avec la température décroissante et atteint une valeur pratiquement constante pour des températures plus basses que $-10^{\circ} \mathrm{C}$; dans l'intervalle entre $-10^{\circ} \mathrm{C}$ et $-2 \mathrm{I}^{\circ} \mathrm{C}, \epsilon_{\mathrm{el}}$ décroit avec la densité croissante, et sa valeur se situe entre $0,7 \mathrm{eV}$ et $0,4 \mathrm{eV}$.

Zusammenfassung. Bestimmung der Aktiverungsenergie polaren Firnes durch Gleichstrom-Widerstandsmessungen. Die Aktivierungsenergie $\epsilon_{\mathrm{el}}$ von Firnproben wurde durch Gleichstrom-Widerstandsmessungen bestimmt; $\epsilon_{\mathrm{el}}$ ist abhängig von der Temperatur und dem spezifischem Gewicht der Proben. Mit abnehmender Temperatur verringert sich der Wert von $\epsilon_{\mathrm{el}}$ im Bereich $-2^{\circ} \mathrm{C}$ bis $-10^{\circ} \mathrm{C}$ und erreicht einen nahezu konstanten Wert unterhalb $-10^{\circ} \mathrm{C}$, wo eine Abnahme von $\epsilon_{\mathrm{el}}$ bei zunehmendem spezifischem Gewicht der Proben im Bereich $-10^{\circ} \mathrm{C}$ bis $-21^{\circ} \mathrm{C}$ beobachtet wurde: die Aktivierungsenergie $\epsilon_{\mathrm{el}}$ liegt in diesem Bereich zwischen $0,7 \mathrm{eV}$ und $0,4 \mathrm{eV}$.

\section{INTRODUCTION}

Interpretation of D.C. resistivity soundings made on the ice sheets of Greenland and Antarctica showed that the resistivity of firn (névé) and ice depends, amongst other parameters, upon the temperature (Hochstein, 1965, 1967). Theoretical studies (mostly summarized in Jaccard (1959)) show that the electrical properties of ice can be explained by the presence of $\mathrm{OH}^{-}$and $\mathrm{H}_{3} \mathrm{O}^{+}$ions and lattice defects; production and annihilation of these defects are governed by activation processes, and the variation of the D.C. resistivity $\rho(T)$ of firn and ice with temperature can be described by an Arrhenius equation:

$$
\rho(T)=\rho_{\mathrm{c}} \exp \left(\frac{\epsilon_{\mathrm{el}}}{k T}\right)
$$

where $\rho_{\mathrm{c}}$ is a constant, $\epsilon_{\mathrm{el}}$ the (average) activation energy, $k$ the Boltzmann constant $\left(8 \cdot 62 \times 10^{-5}\right.$ $\mathrm{eV} .{ }^{\circ} \mathrm{C}$.) and $T$ the absolute temperature. A quantitative interpretation of resistivity soundings on ice using Equation (I) is at present limited by the knowledge of the parameter $\epsilon_{\mathrm{el}}$.

Only a few values for $\epsilon_{\mathrm{el}}$ have been published. Laboratory measurements of $\epsilon_{\mathrm{el}}$ are given by Jaccard (1959) and by Kopp (1962). Jaccard found that for monocrystalline ice $\epsilon_{\mathrm{el}}=0.6 \mathrm{I} \mathrm{eV}$. Measurements by Kopp showed that for snow and firn samples from the Weissfluhjoch $0.7 \mathrm{eV}$. $<\epsilon_{\mathrm{el}}<0.9 \mathrm{eV}$.; higher values $\left(0.8 \mathrm{eV} .<\epsilon_{\mathrm{el}}<\mathrm{I} \cdot 4 \mathrm{eV}\right.$.) were deduced from measurements of firn samples from the central part of Greenland (densities between $0.55 \mathrm{~g} . / \mathrm{cm} .^{3}$ and $\left.0.735 \mathrm{~g} . / \mathrm{cm} .{ }^{3}\right)$ but no relation between $\epsilon_{\mathrm{el}}$ and firn density was found. An interesting result of Kopp's studies was that $\epsilon_{\mathrm{el}}$ of snow apparently depends on its granular structure. The activation energy $\epsilon_{\mathrm{el}}$ of snow undergoing an artificial metamorphosis increased with increasing grain size whereas the activation energy of a snow sample remained about constant during compression by which the density of the sample was increased from $\mathrm{o} \cdot \mathrm{I} 3 \mathrm{~g} . / \mathrm{cm} .{ }^{3}$ to $0.57 \mathrm{~g} . / \mathrm{cm} .^{3}$.

Indirect determinations of $\epsilon_{\mathrm{el}}$ from resistivity sounding curves have been given by Hochstein ( 1965,1967 ); on the Greenland ice sheet it was found that $\epsilon_{\mathrm{el}}$ of the bulk of the ice (depths greater than $50 \mathrm{~m}$.) is relatively small, $0.3 \mathrm{eV} .<\epsilon_{\mathrm{el}}<0.55 \mathrm{eV}$.; a more accurate value for $\epsilon_{\mathrm{el}}$ was obtained from a sounding curve on the Ross Ice Shelf (Antarctica) where the average 
activation energy was found to be $\epsilon_{\mathrm{el}}=0 \cdot 4^{2} \pm 0 \cdot \mathrm{I}_{5} \mathrm{eV}$. (Hochstein, I965) which was later corrected to $\epsilon_{\mathrm{el}}=0 \cdot 3^{8} \pm 0 \cdot \mathrm{r} \mathrm{eV}$. (Hochstein, 1967 ).

The determination of $\epsilon_{\mathrm{el}}$ of firn in the upper $50 \mathrm{~m}$. of ice sheets using information from sounding curves was found to be very difficult. A small resistivity project with the aim of determining $\epsilon_{\mathrm{el}}$ of firn in the density range $0.4-0.8 \mathrm{~g} . / \mathrm{cm} .{ }^{3}$ was therefore planned in connection with a drilling programme on the McMurdo Ice Shelf (Antarctica) during the 1965/66 season. The study consisted of field measurements of temperature, density and D.C. resistivity at various depths in one drill hole on the ice shelf (lat. $77^{\circ} 54^{\circ} \mathrm{o}^{\prime} \mathrm{S}$., long. $166^{\circ} 57 \cdot 5^{\prime}$ E.; ice thickness $=48 \mathrm{~m}$., depth of hole $=3 \mathrm{I} \cdot \mathrm{I} \mathrm{m}$.) and laboratory measurements of the resistivity of several cores at various temperatures. The core studies were made at the Chemistry Division and the Physics and Engineering Laboratory of the D.S.I.R. (Lower Hutt, New Zealand) about four months after the cores were sampled.

\section{Method and Results}

The resistivity of a firn sample (average length of the cores $35 \mathrm{~cm}$., average diameter $7 \cdot 4 \mathrm{~cm}$.) was determined by passing a current $I$ through the core by means of two current electrodes (brass discs) fixed to the ends and measuring the resulting potential drop $\Delta V$ between two potential electrodes (galvanized rings) which were fastened to the middle part of the core. If the cross-sectional area of the core is $A$ and the distance between the potential electrodes $l$, the resistivity is given by:

$$
\rho=\frac{A \Delta V}{l I} .
$$

For reading the current an "AVO" electronic multimeter (ст38) was used; $\Delta V$ was measured with a "Philips" tube voltmeter (GM 602O) and a "Hewlett-Packard" tube voltmeter (4I2A), both instruments having an input impedance $\geqslant \mathrm{I} \times 10^{8} \Omega$. Only small voltages were applied (field strength $\leqslant 2.5 \mathrm{~V} . / \mathrm{cm}$.) in order to avoid polarization. The contact resistance $R_{\mathrm{c}}$ at the potential electrodes was found to be $\mathrm{I} \times 10^{5} \Omega<R_{\mathrm{c}}<2.5 \times 10^{7} \Omega$. Precautions were taken to obtain a homogeneous current distribution by planing the ends of the cores (rubbing on nylon gauze) and by applying a small pressure in fixing the brass discs. Great care was taken to avoid any contamination of the cores, which were never touched by hand. At present we believe that for similar studies in the future it is most important to keep the field strength in the core $\leqslant 2.5 \mathrm{~V} . / \mathrm{cm}$.; violation of this condition will cause either non-reproducible readings, as reported by Østrem (1967) who used fields of $\approx \mathrm{I} 00 \mathrm{~V} . / \mathrm{cm}$., or a scatter of the measurements, as observed by Kopp who applied fields of $\approx 8 \mathrm{~V} . / \mathrm{cm}$.

For a fixed position of the potential electrodes the measurements were reproducible although small variations of the resistivity $(<5$ per cent) could be observed if the current was reversed. Larger variations (occasionally up to 300 per cent) were found when the potential electrodes were shifted to a different part of the core, but these affect $\epsilon_{\mathrm{el}}$ only slightly (see Footnote $\mathrm{I}$ in Table I).

The resistivities of all available cores were determined at the temperature $-3 \cdot 3{ }^{\circ} \mathrm{C}$. Five more or less homogeneous cores were selected for further measurements which were taken at temperatures decreasing in steps of about five degrees from $-5{ }^{\circ} \mathrm{C}$. to $-2 \mathrm{I}^{\circ} \mathrm{C}$. The time which elapsed between two successive readings was about $\mathrm{I} 2 \mathrm{hr}$. The results are shown in Figure $\mathrm{I}$, in which $\log \rho$ is plotted against the reciprocal absolute temperature $\mathrm{I} / T$; the slope of the curves is then proportional to $\epsilon_{\mathrm{el}}$. With the exception of samples $\mathrm{I}$ and $2 \mathrm{~b}$ the resistivities measured at $-3 \cdot 3^{\circ} \mathrm{C}$. do not fall on the curves in Figure I because the positions of the potential electrodes during the measurements at $-3 \cdot 3^{\circ} \mathrm{C}$. were slightly different from those at lower temperatures. The plot shows that for temperatures colder than $-\mathrm{IO}^{\circ} \mathrm{C} . \epsilon_{\mathrm{el}}$ is nearly constant; for temperatures warmer than $-10^{\circ} \mathrm{C}$. $\epsilon_{\mathrm{el}}$ increases with increasing temperature. This agrees with Kopp's measurements, which also show that the slope of the curves is 
constant down to at least $-50^{\circ} \mathrm{C}$. Values of $\epsilon_{\mathrm{el}}$ calculated from the nearly linear part of the curves are compiled in Table I.

Table I. Agtivation Energy $\epsilon_{\mathrm{el}}$ of Polar Firn Between $-10^{\circ} \mathrm{C}$. And $-21^{\circ} \mathrm{C}$.

\begin{tabular}{|c|c|c|c|}
\hline Core & $\begin{array}{c}\text { Activation Energy } \\
\mathrm{eV} .\end{array}$ & $\begin{array}{l}\text { Density } \\
\text { g. } / \mathrm{cm} .3\end{array}$ & Remarks \\
\hline - & $0 \cdot 69$ & 0.22 & Fresh snow (Kopp, 1962) \\
\hline I & 0.665 & $0 \cdot 465$ & 一 \\
\hline $\begin{array}{l}2 \mathrm{a} \\
2 \mathrm{~b}^{\prime}\end{array}$ & $\begin{array}{l}0.62 \\
0.64\end{array}$ & $\begin{array}{l}o .59 \\
0.59\end{array}$ & Same core \\
\hline 3 & 0.615 & 0.655 & 一 \\
\hline 4 & $0 \cdot 47$ & 0.73 & $\overline{0}$. \\
\hline 5 & $0 \cdot 39$ & $0 \cdot 89$ & Salinity $<\mathrm{r}^{\circ} \mathrm{oo}^{2}$ \\
\hline
\end{tabular}

' For the measurement of $\rho(T)$ of sample $2 \mathrm{~b}$ the potential electrodes were shifted to a different part of the core (about 60 per cent overlap with position of potential electrodes of $2 \mathrm{a})$; the absolute value of $\rho(\mathcal{T})$ decreased by about 60 per cent but the slope of $\log \rho$ vs. $1 / T$ remained about constant (Fig. 1$)$. It should be noted that sample $2 \mathrm{~b}$ at $-20 \cdot 9 \mathrm{C}$. was accidentally measured in a field of $10 \mathrm{~V} . / \mathrm{cm}$. which explains the deviation of $\rho(T)$ at this point in Figure 1 .

${ }^{2}$ The core was taken from the brine-infiltrated bottom part of the shelf; it is possible that $\rho(T)$ and $\epsilon_{\mathrm{el}}$ are slightly affected by electrolytic conduction.

Table I shows that the activation energy $\epsilon_{\mathrm{el}}$ of polar firn varies between $0 \cdot 7$ and $0 \cdot 4 \mathrm{eV}$. Although we do not know at present which factors affect $\epsilon_{\mathrm{el}}$, our measurements suggest that in the case of polar firn there is a significant correlation with density. The results of Table I are plotted in Figure 2 which indicates that $\epsilon_{\mathrm{el}}$ decreases with increasing density.

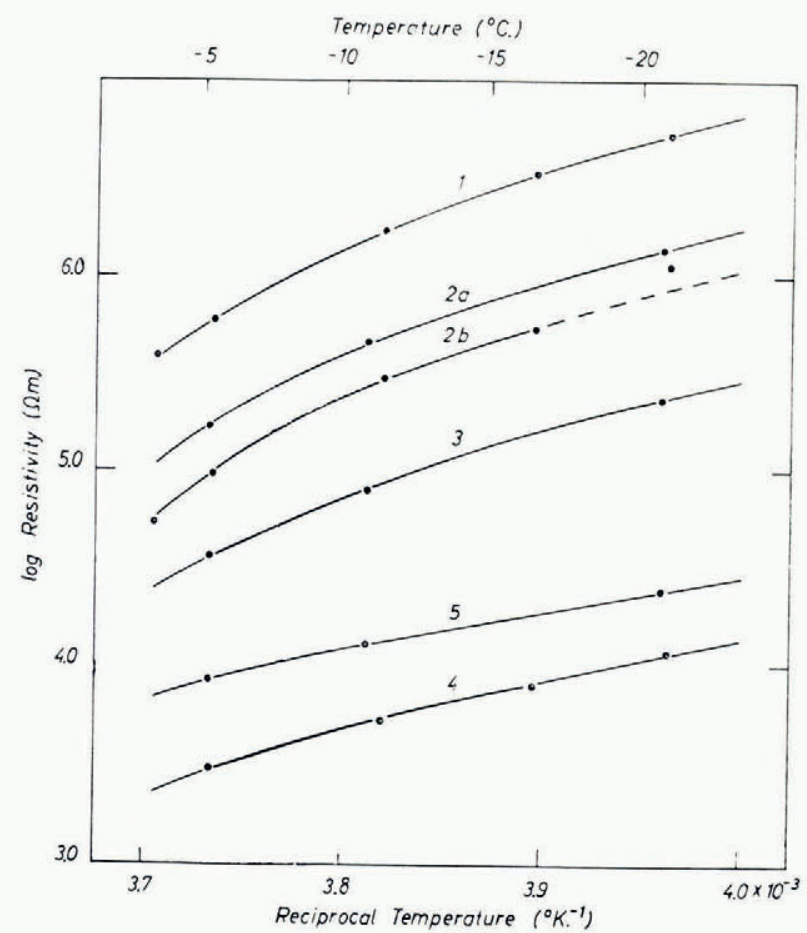

Fig. I. Variation of D.C. resistivity of polar firn samples with temperature: figures indicate sample number (see also Table I) 


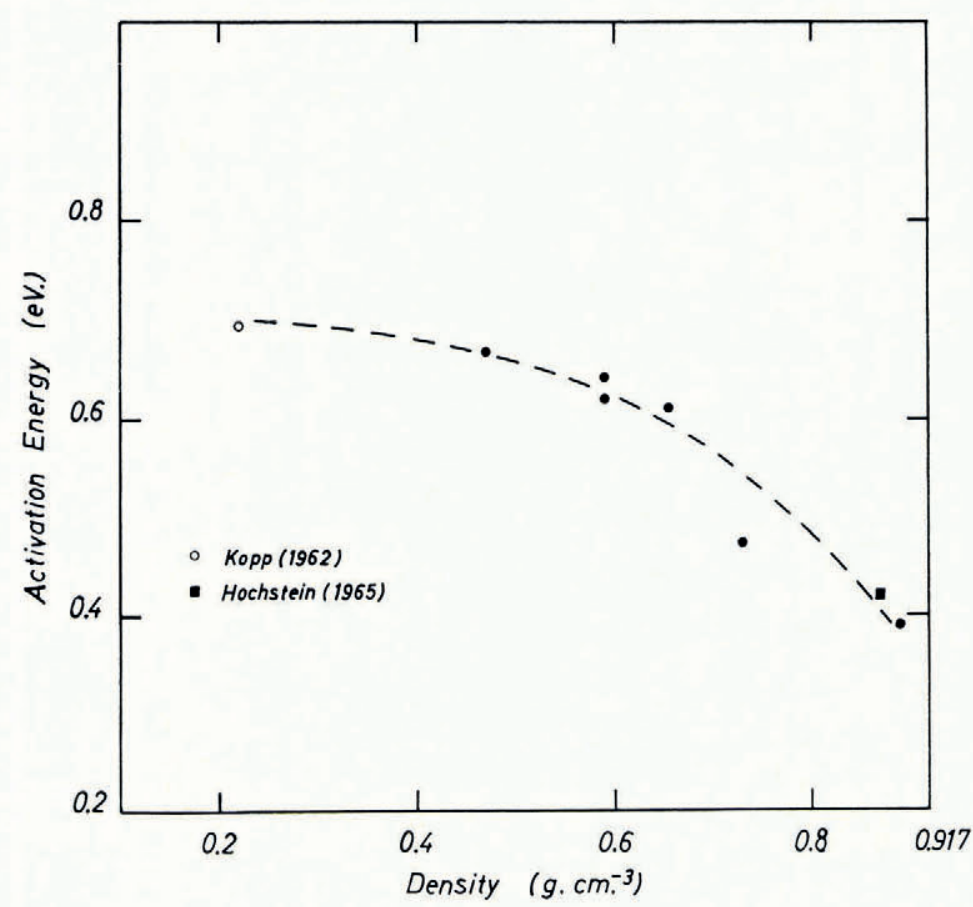

Fig. 2. Activation energy of polar firn samples as a function of density

In this plot are also shown the values of $\epsilon_{\mathrm{el}}$ of fresh snow and shelf ice determined by Kopp and by Hochstein.

A check of the laboratory measurements by comparing them with the resistivities measured in the hole was found to be inconclusive. The resistivity versus depth profile compiled from the core measurements at $-3 \cdot 3^{\circ} \mathrm{C}$. has about the same shape as the logging profile when this had been reduced to the same temperature $\left(-3 \cdot 3^{\circ} \mathrm{C}\right.$.) using Equation (I). However, the core resistivities are about $\mathrm{I} \cdot 5$ to 2 times greater than the corresponding values from the reduced logging profile. At present we believe that small changes of the texture of the cores during transport and storage are responsible for this discrepancy; similar studies in the future should therefore be made in the field.

\section{Conclusion}

The measurement of the D.C. resistivities of firn cores shows that for temperatures between $-10^{\circ} \mathrm{C}$. and $-2 \mathrm{I}^{\circ} \mathrm{C}$. the activation energy $\epsilon_{\mathrm{el}}$ lies between $0.7 \mathrm{eV}$. and $0.4 \mathrm{eV}$. and decreases with increasing density; larger values of $\epsilon_{\mathrm{el}}$ occur at temperatures warmer than $-10^{\circ} \mathrm{C}$. It is concluded that the activation energy $\epsilon_{\mathrm{el}}$ of polar firn is not a constant but a function of temperature and density. A possible explanation of the observed variation of $\epsilon_{\mathrm{el}}$ is that various intra- and inter-crystalline activation processes occur together and that the intracrystalline processes (with relatively low activation energies) are dominant in the highdensity range of polar firn. 


\section{REFERENGES}

Hochstein, M. 1965. Elektrische Widerstandsmessungen auf dem grönländischen Inlandeis. Meddelelser om Gronland, Bd. I 17 , Nr. 3.

Hochstein, M. I967. Electrical resistivity measurements on ice sheets. Fournal of Glaciology, Vol. 6, No. 47, p. 623-33. Jaccard, C. 1959. Étude théorique et expérimentale des propriétés électriques de la glace. Helvetica Physica Acta, Vol. 32, Fasc. 2, p. 89-128.

Kopp, M. 1962. Conductivité électrique de la neige au courant continu. Zeitschrift für angewandte Mathematik und Physik, Bd. 13, Ht. 5, p. 43 I-41.

Østrem, G. 1967. Laboratory measurements of the resistivity of ice. Journal of Glaciology, Vol. 6, No. 47, p. 643-50. 